\title{
THE RIGHTEOUS BANKRUPTCY TRUSTEE: THE INFLUENCE OF CREDITORS ON THE APPOINTMENT OF A BANKRUPTCY TRUSTEE FROM A NETHERLANDS PERSPECTIVE
}

RD Vriesendorp*

\section{Introduction}

The 2007 annual conference organised by the Dutch insolvency practitioners association Insolad deals with the subject matter of 'De integere curator' (the righteous, incorruptible bankruptcy trustee). The first thought that came to mind was that such theme is a pleonasm and superfluous: by definition, a bankruptcy trustee (hereafter shortly referred to as 'trustee') should and must be a righteous person. Otherwise, he or she is unfit to act as such. Or is there something going wrong; are trustees sometimes not righteous? This has been suggested in the media and on the internet.

In this contribution a view is presented on the topic from a Dutch perspective, more specifically from the point of view of the creditors and their (lack of) influence on the appointment of the trustee. Their involvement with the issue of the righteousness or integrity of the trustee can be twofold: they might suffer from acts by the trustee that they consider not to be righteous, but they can also benefit from such acts. With respect to the latter, one should think of creditors who for example were involved in fraudulent conveyance transactions: their concern is to persuade the trustee to overlook those acts.

* Prof Reinout Vriesendorp. Faculty of Law, University of Tilburg. This article is an adaptation of my contribution De invloed van crediteuren op de aanstelling van een integere curator, see Vriesendorp Invloed van Crediteuren 41-50. I would like to thank Colin Anderson, Andre Boraine, David Burdette, Juanita Calitz, Anneli Loubser, John Pottow, Paul Omar and Adrian Walters for providing me with useful material and information on the topic. 
Before the issue of integrity is discussed from the perspective of the creditors, the following questions need to be addressed: what is integrity or righteousness in the context of the topic of this contribution; what is meant by 'a righteous trustee'; why do we need a righteous trustee; and how do we reach our goal ( $\S$ 2)? Next, an investigation follows of the existing safeguards to prevent nonrighteous persons to be enrolled or appointed as trustees (§ 3-4). Subsequently, the position of the creditors in this respect is discussed, with a limited focus on their influence on the appointment of the trustee.

It should be noted that this contribution is based on the current Dutch legal system. However, a quick glance at various neighbouring jurisdictions, demonstrates that not much has been regulated in the Netherlands ( $\S 5$ ). Finally, the question is raised whether or not more creditor involvement in the appointment process is required or desired (§ 6). It shall be argued that there is no need to increase their influence.

\section{$2 \quad$ Integrity and the righteous trustee}

According to the Compact Oxford English Dictionary, righteous means 'morally right or justifiable'. According to the authoritative dictionary of Van Dale in the Netherlands the Dutch noun integriteit (integrity) means: rechtschapenheid (righteousness), onschendbaarheid (immunity) and onomkoopbaarheid (incorruptibleness). Based on the Latin word integer, it refers to the notion of gaafheid (being intact, untouched), ongerept (unspoilt), niet geplunderd (not looted) and in a moral sense it means: onbeslist (undecided), verstandig (sensible, reasonable), zonder vooroordelen (without prejudice), rechtschapen (honourable), onbedorven (untainted), rein van levenswandel (clean in conduct). Paraphrasing, righteousness or integrity implies that the trustee will keep his back straight, set his course and will not be improperly influenced nor act improperly himself. He may not confuse his own interest with the interests that are entrusted to him. 
The integrity of the trustee is an absolute requirement, because it is his or her duty to manage the assets of a person who is declared bankrupt by the court and to dispose of those assets for the benefit of the creditors of that person. The trustee is empowered over another person's estate who himself has been deprived of all control. The right use of his powers and the necessity of abuse by the trustee is not only relevant for the debtor and his creditors, but also required from a societal perspective. The trustee is the person whom the legislator deems fit to wind up the estate of a (legal) person which is insufficient to satisfy the claims of all the creditors. Such winding-up happens, by definition, in an environment of conflicting interests. Hence, the integrity of the trustee is a prerequisite, next to expertise and experience. A trustee should not only be competent as to the material aspects of his or her profession, but must also demonstrate behaviour on which the general public can rely without any hesitation. The latter is even more important as the trustee's remuneration generally depends on the same estate that must satisfy the creditors. This is the case in the Netherlands, where the distribution of the proceeds of the estate with respect to the trustee has priority over all other persons involved. It could raise some doubts whether such person will indeed properly subordinate his own interests to those of the person whose assets he manages or in whose interests he is appointed. Hence, integrity of the trustee is an absolute must.

The prerequisite of integrity is not restricted to one moment in time, like a photograph. It is more like a movie in a sense that integrity is required from the beginning to the end. In other words, the trustee's integrity is imperative from the moment someone informs the court that he would like to be eligible for appointment as trustee until the final statement of accounts of his last bankruptcy. Roughly speaking, this period can be divided into three phases. First of all the phase with respect to the appointment as trustee, which relates both to the application to the court for enrolment on the list of trustees in general on the one hand and the appointment in a specific bankruptcy on the other hand. The second phase deals with the behaviour of the trustee during the bankruptcy in which righteous acting by the trustee is required. He must honourably deal with the debtor's estate, which means that he must carefully manage the assets and prevent unnecessary debts of the estate to arise. This 
coincides with a correct treatment of all persons involved and an adequate (financial) account of his or her actions. This last aspect forms the third and final phase which relates to the termination of a specific bankruptcy: the trustee must then report on his management and administration of the estate and the financial transactions he has performed. As mentioned before, this contribution is limited to a discussion of the first phase, viz of the appointment as trustee: how can it be ensured that only righteous persons, persons of integrity, will be appointed as trustees?

\section{Integrity and the appointment of trustees: enrolment by the court}

As a start, it is relevant to know that Netherlands law does not have any formal requirements to be met before a person can be appointed as a trustee. Any person - in theory even minors or people who lack the capacity to enter into legal acts - could be appointed as trustee. Because the current Faillissementswet (NFw; Dutch Bankruptcy Act; enacted in 1893 and in force since 1896) does not contain any requirements for eligibility as trustee, it does not result in a sorting between righteous and non-righteous persons. In the Dutch insolvency practice, however, the courts almost always appoint lawyers who are members of the bar as trustees. Hence, a certain selection can be reached along this detour, because not everyone is admitted to the bar. For admission one needs to qualify, which means that one has to comply with the statutory requirements set forth in the Advocatenwet (Law on the Bar). First of all these requirements relate to knowledge and competence of the prospective member of the bar. Furthermore, his or her integrity comes into view because a formal document must be submitted, presented by the board of the municipality with respect to one's behaviour (a so-called Verklaring omtrent het gedrag; declaration on behaviour) and to the extent necessary, a declaration that one has not been subject to any disciplinary sanction ${ }^{1}$ nor been declared bankrupt

1 Almost 20 decisions of the last two decades of the Disciplinary Boards (Raden van Discipline) and the ultimate Disciplinary Court (Hof van Discipline) of the Nederlandse Orde van Advocaten (Dutch Bar Association) are related to improper behaviour by lawyers 
nor subject to the Wet schuldsaneringsregeling natuurlijke personen ('Wsnp'; statutory restructuring proceedings for individuals; title III NFW). ${ }^{2}$ Furthermore, integrity is indirectly involved in the admission proceedings to the bar upon making the oath or vow at the court session.

A next possibility for assessing the integrity of a prospective trustee occurs at the time such person approaches the court with the request to be enrolled for appointment as trustee. In this respect the attitude of the courts has changed dramatically in the last decades. Previously, the court more or less as a matter of course appointed any new member of the bar almost immediately as trustee in a simple bankruptcy. Nowadays, however, this will not occur anymore. The courts will appoint persons only as trustee when they consider such person capable and sufficiently experienced to handle the bankruptcy. In the beginning a relatively short and simple extra course in Bankruptcy Law was sufficient for eligibility as trustee during the last period of the formal three-year apprenticeship of the bar. After the introduction of more difficult specialisation courses, developed by Grotius Academie and Insolad in a joint effort with universities, law firms, judges and business lawyers in the beginning of the 1990s, a tendency has arisen that the courts require successful attendance and completion of the Grotius/Insolad course - or similar training - as measurable start qualification. ${ }^{3}$ Last year the courts are even further decreasing the group of persons eligible for appointment as trustee. However, it remains unclear to the outside world on the basis of which exact criteria the courts make their decisions. Through the grapevine it can be heard that some courts also consider the economics for a viable insolvency practice as a relevant factor for eligibility. By doing so, they are able to grant a sufficient number of bankruptcies to all eligible trustees to maintain accurate and adequate knowledge and experience in this area.

in connection with a bankruptcy or as trustee. See NOVA http://www.advocatenorde.nl 16 Feb.

2 Art 2 Advocatenwet.

3 The local guidelines that are published by the courts with respect to their dealing with insolvency show a mix of more or less detailed requirements for appointment. The gist, however, is that each court has limited a number of potential trustees. 
With respect to the courts that require certain professional training it is interesting to note that the requirements for successful completion are primarily focused on the acquisition of knowledge and practical competencies rather than a correct professional attitude. For example the prestigious Grotius/Insolad course on Insolvency law requires a sufficient mark on the average of all coursework and a sufficient result in the final oral exam. ${ }^{4}$ Attitude and behaviour, however, are not taught and integrity in itself is not examined at all. Consequently, successful completion of this course does not provide any guarantee with respect to the integrity of the prospective trustee who requests enrolment on the list of eligible trustees.

Finally, even the Insolad-membership that some courts require or prefer for eligibility does not imply integrity of the trustee. Article 3 of the Articles of Association of Insolad requires only a minimum amount of hours spent on insolvency law and sufficient expertise on the basis of education and experience. A favourable reading of this last requirement might imply that the membership is only open to righteous trustees.

\section{$4 \quad$ Integrity and the appointment as trustee in a specific bankruptcy}

As described above, the first selection has been made by enrolment on the court's list of prospective trustees. The question about the integrity of the trustee becomes acute upon his appointment in a specific bankruptcy. According to paragraph 6 of the Bankruptcy Guidelines ${ }^{5}$, the court's clerk immediately approaches the prospective trustee after the court session where the debtor has been declared bankrupt. The sole purpose is to check whether or not there is a (potential) conflict of interest. Although important, the issue of conflicting interests is only one of the aspects of integrity. In the event there is no conflict of interests "then the trustee will be appointed" according to the

4 Art 4 of the Examination Rules of the Grotius/Insolad course.

5 These so-called RECOFA-Richtlijnen (REchters-COmmissarissen in FAillissementen; Bankruptcy Guidelines), made up by the joint judges-delegates of all District Courts in the Netherlands who supervise individual bankruptcies were introduced in the last part of the previous century and lastly revised per RECOFA http://www.rechtspraak.nl/ 18 Feb. 
compelling language of this provision in paragraph 6.1. Nonetheless, this is not all: before the court's clerk approaches the prospective trustee the court has already made a selection of this person. The selection process is normally an unclear and mystic process that occurs in secrecy within the walls of the closed courtroom, where judge and clerk determine the prospective trustee to be appointed. In this process, various aspects are relevant, as I have become anecdotally aware from discussions with bankruptcy judges(-delegate). Depending on the (expected) size of the bankruptcy, earlier experiences with possible trustees (with respect to their procedural handling of the bankruptcy as well as their material treatment of the issues involved), appreciation or complaints regarding previous bankruptcies, the court decides who it will appoint. Also, the court will take into account how often the prospective trustee (or any other person of his or her law firm) has been recently appointed. Furthermore, personal preferences of the judge sometimes influence the choice of the trustee. ${ }^{6}$ Dealing with all these aspects should result in an adequate, vigorous and trouble-free treatment of the prospective bankruptcy. In this respect integrity is presupposed, because a non-righteous person will be removed from the court's list. However, integrity as such is in itself not a touchstone anymore at this stage.

\section{$5 \quad$ Role of the creditors}

In this contribution to this point, creditors and their role in the appointment process have not been discussed. This is because creditors are not involved in this process in the Netherlands. Not only in the event the debtor requested its own bankruptcy - in which case creditors are normally not involved at all - but also if a creditor has filed for bankruptcy, his role in the appointment process is quite negligible. In the absence of the debtor against whom the petition is filed by a creditor, the court is sometimes inclined to ask the creditor for information

6 With the risk that the appointment of the trustee is not an impartial process, as seemed to have occurred quite often at the time of the enactment of the present Bankruptcy Act in 1893. Such risk, however, seemed - and seems - not to be cured with statutory measures; Van der Feltz Geschiedenis 324. 
about the debtor. Normally, however, the court does not discuss the person of the prospective trustee - and certainly not his integrity - with the creditor. Only after the trustee is indeed appointed and has begun his activities in the bankruptcy, the issue of his integrity starts playing a role. From that moment, creditors may approach the rechter-commissaris (judge-delegate) who supervises the trustee in the specific bankruptcy, with complaints about the (integrity of the) trustee. They can elicit an order from the judge-delegate on the basis of article $69 \mathrm{FW}$, ordering or prohibiting certain actions with respect to the management and administration of the estate by the trustee. In the context of the integrity issue, one could think of a trustee extracting assets from the estate or the sale of assets to friends or related parties below market value. ${ }^{7}$ Pursuant to article $73 \mathrm{Fw}$ those creditors may in grievous circumstances even request the court to dismiss the trustee. ${ }^{8}$

All in all, the influence of the creditors with respect to the appointment of a trustee is almost absent in the Netherlands, not to mention that issues concerning the trustee's integrity are not dealt with at all. Is there no other option or do alternatives exist? What happens for example in our neighbouring countries?

\subsection{Germany}

Pursuant to § 56 paragraph 1 Insolvenzordnung ('InsO'; German Insolvency Act) the following person is eligible for appointment as Insolvenzverwalter (bankruptcy trustee) in our eastern neighbouring jurisdiction:

eine für den jeweiligen Einzelfall geeignete, insbesondere geschäftskundige und von den Gläubigern und dem Schuldner unabhängige natürliche Person [...], die aus dem Kreis aller zur

$7 \quad$ Eg disciplinary rulings of the Disciplinary Board Leeuwarden of 27 March 1987 and 15 March 1991 (Disciplinary Board Leeuwarden Advocatenblad 1988 and 1992).

8 Rechtbank (District Court) Rotterdam 21 June 2007, LJN BA7841. In Hoge Raad (Supreme Court) 22 September 2006, LJN AY5700, conflicting behaviour did not result in dismissal of the trustee, according to the preceding opinion of Advocate-General Timmerman. Available at http://www.rechtspraak.nl. 
Übernahme von Insolvenzverwaltungen bereiten Personen auszuwählen ist. ${ }^{9}$

However, contrary to the situation in the Netherlands, creditors in a German insolvency have a direct opportunity to exert influence on the appointment of the trustee, without being forced to use the detour of dismissal of the trustee. According to $\S 57$ InsO the creditors can propose by majority vote in the first Gläubigerversammlung (creditors' meeting) another person to be appointed as trustee. Only if this person is considered not to be suited for handling the insolvency, the court will refrain from the appointment. The mere fact that this person has been chosen on recommendation of the largest creditor does not make him unsuitable. ${ }^{10}$ Comparable to the Dutch situation is that the German trustee may be dismissed by the court for an important reason ( $\$ 59$ InsO). The provisions concerning appointment and dismissal in §§ 56-59 InsO form an exhaustive and exclusive system, as the German Supreme Court decided in the beginning of $2007 .^{11}$

\subsection{Belgium}

The selection and appointment of the trustee is extensively dealt with in the Faillissementswet (BFw; Belgian Bankruptcy Act) of our southern neighbouring jurisdiction. Pursuant to article $11 \mathrm{BFw}$ the trustee will be elected from a list of eligible persons. This group has been designated by the Rechtbank van Koophandel (Commercial Court) in accordance with article 27 BFW. Refusal to be put on that list or deletion from that list is subject to judicial review (article 28 $B F w)$. However, only persons that are admitted to the bar may be placed on the list after completion of a special training and demonstration of their competence with regard to insolvency proceedings. One could argue that these requirements imply integrity of the trustee, as also seems to be confirmed by

9 Translation: "An independent individual suited to the specific case at hand, independent of the creditors and of the debtor, to be chosen from the group of persons experienced in administering insolvencies."

10 BGH 17.7.2003 - IX ZB 530/02 Bundesgerichtshof (German Supreme Court) available at http://www.bundesgerichtshof.de/.

11 BGH 25.1.2007 - IX ZB 240/05. 
the provision in article $40 \mathrm{BFW}$ containing the general duty of care imposed on the trustee: he must administer the bankruptcy as a 'good housefather' under supervision of the judge-delegate. With respect to the specific issue of conflicting interests, Belgian law contains an explicit and rather extensive regulation in articles 30-32 BFW: upon acceptance of his appointment, the trustee is obliged to inform the court of any activity, by himself or any of his partners or direct associates in his firm, other than acting as trustee, on behalf of the bankrupt (legal) person, its directors or representatives or any creditor during the last 18 months prior to the bankruptcy. ${ }^{12}$ In such case the court has the discretion to forgo the appointment or - if the conflicting interest appears after the appointment as trustee - to dismiss the trustee (article $31 \mathrm{BFw}$ ) or to appoint temporarily a special trustee, the curator ad hoc (article $32 \mathrm{BFw}$ ). However, Belgian law does not contain any provision requiring a specific involvement of the creditors with respect to the appointment of the trustee.

\subsection{France}

France has a variety of insolvency proceedings in connection with the restructuring of enterprises. One of the central persons in such proceedings is the so-called mandataire judiciaire (court-appointed receiver). It is his or her duty to represent the creditors and to liquidate the assets of the enterprise. ${ }^{13}$ Due to various scandals and excesses in the treatment of insolvencies in the last decade of the $20^{\text {th }}$ century because of narrow ties between the court and certain insolvency practitioners, the insolvency legislation was amended in $2003 .{ }^{14}$ Currently, the appointment as mandataire judiciaire requires various quality requirements to be met. ${ }^{15}$ Pursuant to these provisions the mandataire judiciaire must be enrolled on a national list of insolvency practitioners. ${ }^{16}$

12 Art 30 BFw. According to the - originally in 2002 amended art 30 BFw this information had to be filed with the - public - bankruptcy file kept by the court. The Belgian Arbitragehof (Court of Arbitration 24 March 2004, 50/2004) annulled this part of the amendment because of the disproportionality. 
According to article L.812-3 Code de Commerce (CdC; French Commercial Code) such person must fulfil several requirements, partly related to his nationality (French nationality or citizen of another EU-member state), partly to his behaviour (no criminal, administrative or disciplinary sanctions arising from indecent or dishonest behaviour (faits contraires à l'honneur ou à la probité) nor being subject to any of the French insolvency proceedings) and partly to his competence (successful completion of the apprenticeship in the field of insolvencies). ${ }^{17}$ Moreover, the insolvency practitioners have adopted a code of conduct (Charte qualité des administrateurs et des mandataires judiciaires) pursuant to which they will behave conform governmental professional rules and (ethical) standards. ${ }^{18}$

Subsequently, the mandataire judiciaire will be appointed in a specific insolvency proceeding, provided that he demonstrates that he has not been in any way involved with the (legal) person subject to the insolvency proceeding since five years prior to his appointment. ${ }^{19}$ It is, however, the discretion of the court to determine which mandataire judiciaire it will appoint from the national list. In this respect, creditors do not have any specific role.

\section{Towards more creditor involvement in the appointment process?}

Against the background of the developments in the surrounding jurisdictions one could raise the question if, and to what extent, more attention should be paid to the integrity of the trustee, as seen from the creditors' perspective and in view of the limited scope of this contribution - more in particular, their involvement in the appointment process in the Netherlands. Apart from the question if such involvement would be possible (which, personally, it is thought to be), a more important question is whether such involvement would also be necessary.

17 AJMJ Devenir mandataire de justice http://www.ajmj.fr/ 27 Feb.

18 AJMJ Charte http://www.ajmi.fr/ 27 Feb.

19 Art L812-2 CdC. 
A nuanced answer - yes and no - might be expected; however is not what is proposed. On the one hand, more involvement can be justified by the fact that an insolvency in the Netherlands will ultimately affect the value of the creditors' claims. They have entered into a relationship with the debtor who does not perform his or her obligations. Most likely, they have or should have at least some insight in the activities of the debtor. As a result, they will be the most appropriate party to choose the most successful trustee. Indeed, if they choose the wrong person, they will notice the adverse consequences in their wallet. On the other hand, more involvement of the creditors in the appointment process could result in the risk that a partial trustee might be appointed. It is not always clear who are the relevant parties, including the most important creditors, in the period just before the declaration of the bankruptcy. The concurrence of the creditors in this chaotic and hectic period often creates a situation where it might be doubtful that the trustee who is proposed by certain creditors is sufficiently impartial with respect to the interests of those creditors. This is considered a significant impediment against more creditor involvement, because it is the primary duty of the trustee to deal correctly with all creditors' often conflicting - claims in accordance with their respective ranks. It is not so strange that exactly this aspect of potential conflicting interests plays a significant role in our surrounding jurisdictions. Although possible, more involvement of the creditors in the appointment process is therefore opposed.

\section{$7 \quad$ Final remarks}

The negative answer to the question whether creditors should become more involved in the appointment process of the trustee in the Netherlands, does not mean that the creditors should not interfere with the administration of the bankrupt estate by the trustee afterwards. To the contrary, it is their fundamental right to be involved and to keep an eye on the trustee. In the event he or she does not like such active creditors, then their appointment should not be accepted. Eventually, the judge-delegate who might get involved by too active and meddlesome creditors requesting him or her court-orders against the trustee on the basis of article $69 \mathrm{NFW}$, can - and must - resist such actions 
should they result in too much delay and extra costs. The court will and can only do so with sufficient authority, provided that trustees demonstrate an impeccable behaviour.

The same applies to the appointment process by the court. This must be a transparent and verifiable process in order to prevent partial practices, such as the ones that occurred in France at the end of last century ${ }^{20}$ or by certain Dutch courts before our present Bankruptcy Act was enacted at the end of the $19^{\text {th }}$ century. ${ }^{21}$ Statutory provisions fail to prevent such abuse, as was already observed at that time. Such prevention is only possible if there is an attitude of candour by the court: towards the trustees, creditors, debtor and all other parties involved. However, it is not considered necessary to create a closed, well-regulated profession of insolvency practitioners, like nowadays for example in France and England. In a contribution in the Dutch Insolvency Law Review in 2005, the introduction of an autonomous disciplinary rules system for Dutch trustees has already been suggested. ${ }^{22}$ In combination with thorough education (with exams) and practical competence requirements, such rules could justify the formation of a closed community, or at least a preference in the appointment as trustee by the court. In view of the current topic, the trustee's integrity might be added as a separate issue, although it will not require specific rules or legislation. Such rules seem quite useless where it will probably result in risky behaviour testing the boundaries, with all its consequences and only the appearance of certainty. ${ }^{23}$ Hence, the preliminary draft for a new Dutch Insolvency Act that was presented to the Dutch Minister of Justice on November $1,2007,{ }^{24}$ does not contain any provision to that extent. Moreover, such regulation of the integrity of the trustee seems superfluous. Was it not a long time ago that the famous Roman emperor Justinian, following the brilliant

20 Omar Reforms 111-150.

21 Parliamentary Report, art 13 (now 14) NFw, Van der Feltz Geschiedenis 324.

22 Vriesendorp 2005 TVI 11.

23 A typical example can be found in the practice rules and the discussions of these rules; see Insolad http://www.insolad.nl/ 18 Feb. According to some practitioners, these rules are mere an open door and lack a specific meaning; others consider the scope of the rules unclear. The instrument of the English Insolvency Practitioners Regulations is in my view an example of rules that overshot themselves; see English Insolvency Practitioners Regulations http://www.opsi.gov.uk/ 18 Feb.

24 See Justitie http://www.justitie.nl/ 18 Feb. 
lawyer Ulpian, ordered that one has to live an honourable life (honeste vivere) $?^{25}$ This means that a court should not hesitate to take adequate measures - in accordance with the fundamental principles of due process (such as audi alterem partem) - if in a dispute between (one of) the creditors and the trustee, the latter's integrity is at stake. A person is either righteous or not - there is nothing in between - and a trustee is supposed to be righteous. In case a trustee lacks integrity, such person is unfit for his or her office and there can only be one remedy: he or she should not be available anymore as trustee and to the extent necessary, must be removed from any trustees' list or register. 


\section{Bibliography}

Disciplinary Board Leeuwarden 1988 Advocatenblad

Disciplinary Board Leeuwarden "Disciplinary rulings: 27 March 1987" Advocatenblad (22 January 1988)

Disciplinary Board Leeuwarden 1992 Advocatenblad

Disciplinary Board Leeuwarden "Disciplinary rulings: 15 March 1991" Advocatenblad (16 January 1992)

Omar Reforms 111-150

Omar PJ "Reforms to the Framework of Insolvency Law and Practice in France: 1996-2006" in Broc GK and Parry R (eds) Corporate Rescue: An Overview of Recent Developments $2^{\text {nd }}$ ed (Kluwer Deventer 2006)

Van der Feltz Geschiedenis 324

Van der Feltz GW Geschiedenis van de Faillissementswet I (De Erven F Bohn Haarlem 1896)

Vriesendorp 2005 TVI 11

Vriesendorp RD "Transparantie en zelfregulering: VIA Insolad naar VIS?" 2005 TVI 11

Vriesendorp Invloed van Crediteuren 41-50

Vriesendorp R "De Invloed van Crediteuren op de Aanstelling van een Integere Curator" in De Ranitz SH et al (ed) De Integere Curator Insolad Yearbook 2007 (Kluwer Deventer 2007)

\section{Register of legislation}

Advocatenwet (Dutch Law on the Bar)

Code de Commerce (CdC) (French Commercial Code)

Faillissementswet (BFw) (Belgian Bankruptcy Act)

Faillissementswet (NFw) 1896 (Dutch Bankruptcy Act)

Insolvenzordnung (InsO) (German Insolvency Act) 
Wet schuldsaneringsregeling natuurlijke personen (Wsnp) (Statutory

restructuring proceedings for individuals)

\section{Register of court cases}

Arbitragehof 24 March 2004 50/2004

BGH 17.7.2003 - IX ZB 530/02

BGH 25.1.2007 - IX ZB 240/05

Hoge Raad 22 September 2006 LJN AY5700

Rechtbank 21 June 2007 LJN BA7841

\section{Register of Internet resources}

AJMJ Charte http://www.ajmi.fr/ 27 Feb

Conseil National des Administrateurs Judiciaires Charte Qualite des

Administrateurs et des Mandataires Judiciaires [Found on internet]

http://www.ajmi.fr/charte qualite/38.FR.php [Date of use 27 February 2008]

AJMJ Devenir mandataire de justice http://www.ajmj.fr/ 27 Feb

Conseil National des Administrateurs Judiciaires Devenir mandataire de justice [Found on internet]

http://www.ajmi.fr/devenir mandataire/33.FR.php [Date of use 27 February 2008]

English Insolvency Practitioners Regulations http://www.opsi.gov.uk/ 18 Feb

English Insolvency Practitioners Regulations Statutory Instruments 2005 No 524 [Found on internet]

http://www.opsi.gov.uk/si/si2005/uksi 20050524 en.pdf [Date of use 18 February 2008]

Insolad http://www.insolad.nl/ 18 Feb

Insolad Praktijkregels [Found on internet]

http://www.insolad.nl/overinsolad/praktijkregels [Date of use 18 February 2008] 
Justitie http://www.justitie.nl/ 18 Feb

Ministerie van Justitie Commissie insolventierecht Voorontwerp Insolventie Wet 2007 [Found on internet]

http://www.justitie.nl/images/VoorontwerpInsolventiewet tcm34-87549.pdf [Date of use 18 February 2008]

NOVA http://www.advocatenorde.nl 16 Feb

Nederlandse Orde van Advocaten Disciplinaire uitsprake deur de Raden van Discipline en de Hof van Discipline [Found on internet]

http://www.advocatenorde.nl/algemeen/organisatie/disciplinaire uitspraken. asp [Date of use 16 February 2008]

RECOFA http://www.rechtspraak.nl/ 18 Feb

Rechters-commissarissen in Faillissementen Richtlijnen voor faillissementen en surseances van betaling 2004 [Found on internet] http://www.rechtspraak.nl/NR/rdonlyres/17A7E56D-3B7A-4CC8-86635BBD10AB1675/0/Rrrichtlijnenjuli2004doc.pdf [Date of use 18 February 2008]

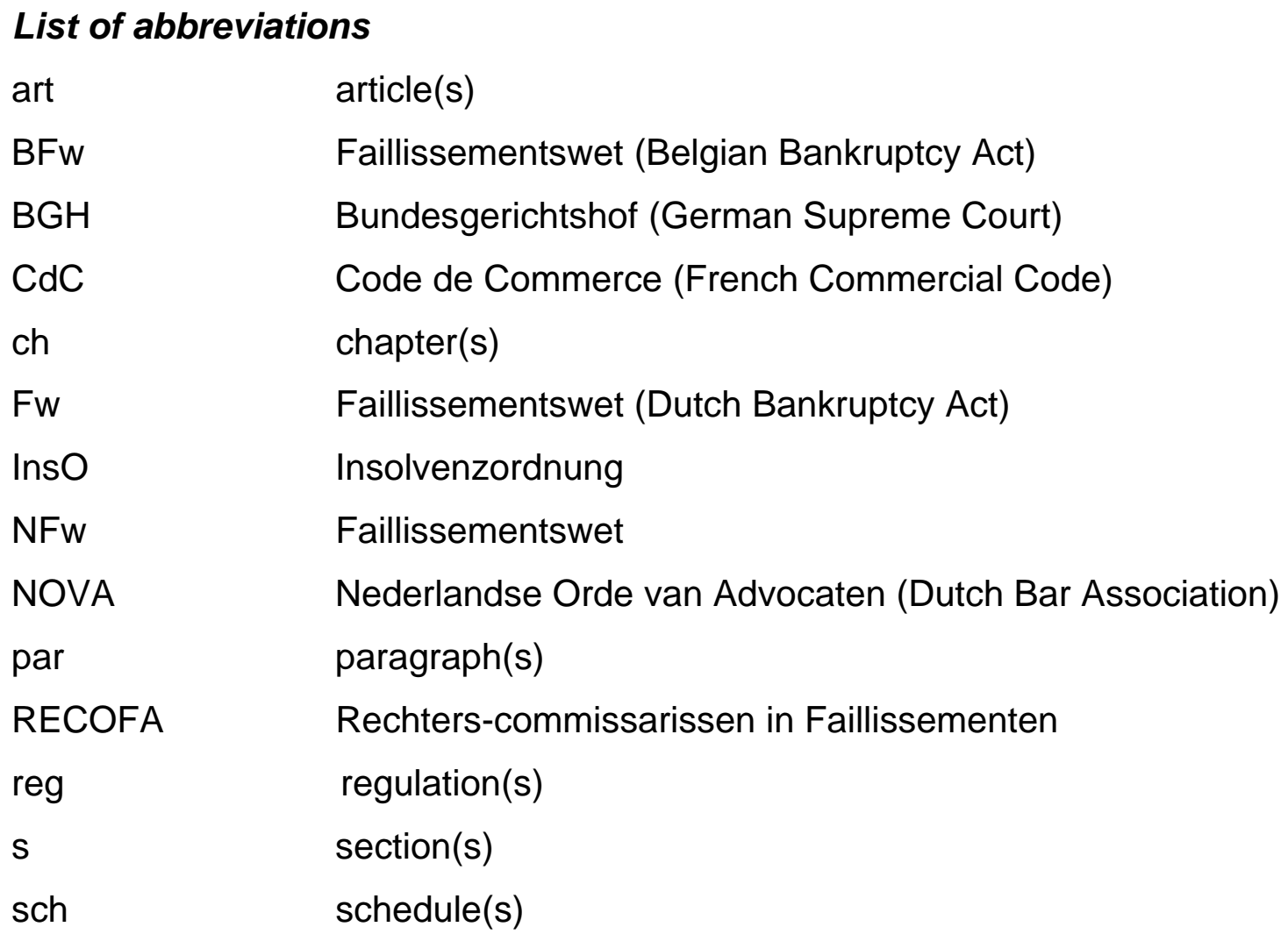


Wet schuldsaneringsregeling natuurlijke personen 